\title{
The philosopher Socrates had exophthalmos (a term coined by Plato) and probably Graves' disease
}

\author{
Peter D. Papapetrou \\ M.D., Endocrinology, Athens, Greece
}

\begin{abstract}
According to a previously published theory, Socrates was afflicted with temporal lobe epilepsy since his childhood. Plato, Xenophon, and Aristoxenus described Socrates as having exophthalmos, probably diplopia, and some symptoms compatible with hyperthyroidism. Using these data, we theorize that Socrates had Graves' disease. In order to determine a cause of his temporal lobe epilepsy, we speculate that the philosopher also had autoimmune thyroiditis and Hashimoto encephalopathy during his childhood and his epilepsy may have been a sequel to this hypothesized encephalopathy.
\end{abstract}

Key words: Exophthalmos, Graves' disease, Hashimoto encephalopathy, Socrates

\section{INTRODUCTION}

Plato, Xenophon, and Aristoxenus provide a good deal of biographical data concerning the appearance and personality of Socrates. Using this information we propose that Socrates had Graves' disease.

Muramoto and Englert ${ }^{1}$ in their well documented article theorized that Socrates very likely had temporal lobe epilepsy (TLE). These authors based their diagnosis on the Socrates' daemonion and his bizarre postures but they did not discuss possible causes of the disease. Socrates on many occasions used to hear a voice urging him not to do or say something which he was about to do or say. He considered that

Corresponding author:

Peter D. Papapetrou,

51 Panagiotou Street, 15669 Papagou, Greece,

Tel.: 2106536669, Fax: 2106537467, E-mail: pdpap@otenet.gr

Received 23-07-2014, Accepted 04-09-2014 the voice was coming from a daemonion. In ancient Greek the word daemonion meant a divine power or deity, or else an inferior divine being, this being quite distinct from the word demon in English or daemonion in modern Greek which signifies either an evil supernatural being or, colloquially, acumen or even a genius, flair. Several interventions of the daemonion arising in Socrates are mentioned in Plato and Xenophon (Plato's Republic 496 C, Apology 40 A-C, Euthyphro 3B, Phaedrus 242 C, Euthydemus 272 E, Theaetetus 151 A, Republic 496 C, Alcibiades 103 A, Theages 129 E, and Xenophon's Symposium 8, 5, Apology 4, 5, and 12-13, and Memorabilia 4, 3, 12). In Plato's Apology 31 C-D, Socrates speaks in front of his judges as follows: "Perhaps it may seem strange that I go about and interfere in other people's affairs to give this advice in private, but do not venture to come before your assembly and advise the state. But the reason for this, as you have heard me say at many times and places, is that something divine and 
spiritual (daemonion in the Greek text) comes to me, the very thing which Meletus ridiculed in this indictment. I have had this from my childhood; it is a sort of voice that comes to me, and when it comes it always holds me back from what I am thinking of doing, but never urges me forward. This it is which opposes my engaging in politics". ${ }^{2}$ Based on the above statement Socrates could have been affected by TLE since his childhood. ${ }^{1}$ We hypothesize that the philosopher may have been afflicted with Hashimoto encephalopathy in his youth and this might have been the cause of a putative TLE. Muramoto and Englert ${ }^{1}$ remark that there is no indication that Socrates had generalized seizures, nor chronic progressive cognitive decline, and therefore his epilepsy would have been mild, stable, and relatively benign.

\section{EVIDENCE FOR GRAVES' DISEASE}

\section{Socrates had exophthalmos}

Socrates had protruding, staring eyes. Xenophon in the Symposium (ch. 5) recounts a beauty competition between Socrates and the handsome young Critobulus: ${ }^{3}$

S. Do you think beauty exists in man alone, or in anything else?

C. I believe it is found in horse and ox and many inanimate things. For instance, I recognize a beautiful shield, sword, or spear.

S. And how can all these things be beautiful when they bear no resemblance to each other?

C. Why, if they are well made for the purposes for which we acquire them, or well adapted by nature to our needs, then in each case I call them beautiful.

S. Well then, what do we need eyes for?

C. To see with, of course.

S. In that case my eyes are at once proved to be more beautiful than yours, because yours look only straight ahead, whereas mine project so that they can see sideways as well.

C. Are you claiming that a crab has the most beautiful eyes of any animal?
S. Certainly, since from the point of view of strength also its eyes are best constructed by nature.

This dialogue provides evidence that Socrates had a remarkable degree of exophthalmos.

That Socrates had protruding eyes is also mentioned in Plato's Theaetetus 143E. Theodorus, a participant in this dialogue, recounts: "Yes, Socrates, I have met one very remarkable Athenian youth, whom I commend to you as well worthy of your attention. If he had been beautiful I should have been afraid to praise him, lest you should suppose that I was in love with him; but he is not beautiful, and you must not be annoyed if I say that he is very like you regarding his snub nose and his projecting eyes (to exo ton ommaton in the Greek text), although these features are less marked in him than in you".

We may also read in Theaetetus 209 B-C:

S. Come on, by Zeus! How in that case could I have formed a judgment of you any more than of any one else? Suppose that I imagine Theaetetus to be a man who has nose, eyes, and mouth, and every other member complete; how would that enable me to think more about Theaetetus than about Theodorus, or as the proverb says, about the last of the Mysians?

T. How could it?

S. Or if I thought about not only him who has nose and eyes, but also about him who has a snub nose and is an exophthalmos (ton exophthalmon in the Greek text, meaning "him who has bulging eyes"), should I have any more notion of you than of myself or others who resemble us?

\section{T. Certainly not.}

The extant ancient statues portray Socrates without protruding eyes, although both Plato and Xenophon make reference to Socrates' exophthalmos. Diogenes Laertius in his "Life of Socrates" (Book 2, Chapter 5,43 ) recounts that the Athenians honored Socrates after his death with a bronze statue, the work of Lysippus. This statue is lost, and it seems unlikely that any statue of the philosopher was made during his life time. ${ }^{3}$ Nails, commenting on Socrates' strangeness wrote: "The extant sources agree that Socrates 
was profoundly ugly, resembling a satyr more than a man - and resembling not at all the statues that turned up later in ancient times and now grace Internet sites and the covers of books". 4

\section{Socrates had eyelid retraction and was probably afflicted with diplopia}

The way in which Socrates sometimes gazed was peculiar. He often stared with eyes wide open at people, a gaze compatible with the eyelid retraction that characterizes Graves' ophthalmopathy. In Phaedo 86D we read: "Then Socrates looked with wide open eyes (diablepsas in the Greek text) at us, as he often used to do, smiled and said...."

A passage in Phaedo (117B) describing the moment when Socrates drank the conium reads as follows: "At the same time he (the man who was to administer the poison) held out the cup to Socrates. He took it and, very gently, Echecrates, without trembling or changing color or facial expression, looked up from under (hypoblepsas in Greek) at the man like a bull (tauredon in Greek) as was his custom, and said: What do you say to pouring a libation to someone from this cup?". Plato probably meant that Socrates tilted his chin upward in order to look at the man. In Graves' ophthalmopathy, with clinical involvement of the extraocular muscles, limitation of the upward gaze is the most common finding caused by tethering of the inferior rectus muscle by inflammation and fibrosis. The patient often tilts the chin upward to gain fusion of the lower fields of vision. ${ }^{5}$ Although no diplopia is explicitly described in Plato, hypothesizing that Socrates was affected by exophthalmos, we infer that his peculiar gaze could be ascribed to unstable diplopia.

\section{Socrates had symptoms compatible with hyperthyroidism}

Alcibiades recounts in Plato's Symposium (220 A-B) that on the Potidaean campaign, Socrates walked over the icy ground in the fierce Thracian winter barefoot and clad as at home. ${ }^{3}$ It is possible that during the Potidaean campaign Socrates was mildly thyrotoxic and thus was tolerant to cold. Xenophon also testifies to Socrates' tolerance to cold in Memorabilia 1,2,1 and 1,6,2; it should be noted, however, that in both these passages Xenophon attests that Socrates was pre-eminently capable of enduring not only winter's cold but also summer's heat.

In their works, Plato and Xenophon emphasized Socrates' self-control and temperance. Aristoxenus, however, claimed to have heard from his father Spintharus, who was one of those who had met Socrates, that Socrates occasionally was seized by bouts of nervousness and anger, speaking and acting violently. ${ }^{3}$ However, it should be noted that Socrates was the most persuasive of men, in part because he usually did not lose his temper, and that, given his normal behavior, these outbursts were all the more striking. ${ }^{6}$ It is possible that this exceptional behavior which was not in keeping with Socrates' character and philosophical attitude occurred mainly during spells of active hyperthyroidism. Xenophon also gives an instance of Socrates' erupting anger (Memorabilia 1,2,29-30): Critias had been attempting to seduce a youth in Socrates' circle called Euthydemus. When private remonstration had had no result, Socrates, seeing him behaving badly at a talk where Euthydemus and several other youths were present, said, angered, before them all, "Critias seems to be overcome by a swinish desire to rub himself against Euthydemus like a pig on a stone". ${ }^{3}$

Socrates was not keen on drinking wine but whenever he was obliged to drink in a symposium he was able to outdrink anyone, and, most incredible of all, no man ever saw Socrates drunk (Plato's Symposium 220A). This ability to tolerate excess of ethanol might be due to hyperthyroidism, which is characterized by increased ethanol metabolism, ${ }^{7}$ and Socrates' reputation for tolerance to alcohol may have arisen during spells of active hyperthyroidism.

\section{DISCUSSION}

Muramoto and Englert ${ }^{1}$ meticulously established that Socrates in all likelihood was afflicted with TLE since his childhood; however, these authors did not suggest any cause for this illness which played a pivotal role in the philosopher's life. We have found evidence in Plato and Xenophon that Socrates could well have had exophthalmos. Moreover, we believe that his peculiar gaze as described in Phaedo is suggestive of diplopia. Plato and Xenophon did not mention that Socrates at any time suffered an attack 
of irascibility or anger, though this may be due to the fact that neither Plato nor Xenophon was concerned with providing an historical account of Socrates. ${ }^{6}$ In contrast, Aristoxenus of Tarentum, the great music theorist and member of the Lyceum under Aristotle, seems to have written the first impartial biography of Socrates. ${ }^{6}$ The doubts of some scholars about the reliability of Aristoxenus should be considered as unfounded. ${ }^{6}$

Taking into account that Socrates had exophthalmos, probably diplopia, and symptoms such as episodic irritability and anger, as well as tolerance to cold, it is reasonable to theorize that the philosopher may have had Graves' disease. From the available information it is not known at what age Socrates developed exophthalmos.

It is noteworthy that Plato mentions Socrates as being 'an exophthalmos', meaning that Socrates was a person with protruding (i.e. bulging or sticking out) eyes (exo meaning out and ophthalmos meaning eye) (Theaetetus 209 B-C). It seems that Plato was the first to coin the term exophthalmos and used it to signify an individual having protruding eyes. However, in contemporary medicine the term exophthalmos is used to denote solely the protrusion of the eyes, not the person carrying the lesion.

Graves' disease and autoimmune thyroiditis coexist in many patients and often Graves' disease may develop against a background of preexisting Hashimoto's thyroiditis. Assuming that Socrates had Graves' disease and in order to determine a probable cause of his putative TLE, we speculate that the philosopher also had autoimmune thyroiditis and was afflicted with Hashimoto encephalopathy during his childhood, while his TLE may have been a sequel to such a case of encephalopathy. Hashimoto encephalopathy, also known as steroid-responsive encephalopathy associated with autoimmune thyroiditis or more accurately as encephalopathy associated with autoimmune thyroiditis (EAT), may appear as an acute severe malady with high morbidity and mortality if not treated with corticosteroids. ${ }^{8}$ However, cases of relatively mild chronic and relapsing Hashimoto encephalopathy have also been reported. ${ }^{9}{ }^{10}$ Simple partial or complex partial seizures similar to those which affected Socrates ${ }^{1}$ have been associated with
Hashimoto encephalopathy; ${ }^{9-12}$ the fact that Hashimoto encephalopathy sometimes involves the temporal lobe ${ }^{9,10,12}$ supports the hypothesis that Socrates' TLE may have been a lifelong post-encephalopathy sequel.

A limitation of our hypothesis that Hashimoto encephalopathy may be a possible cause of the philosopher's TLE is the uncertainty expressed in recent literature concerning the nature of this encephalopathy. By definition, EAT is an encephalopathy of unknown etiology affecting patients with high titers of thyroid autoantibodies. The existence of EAT as a distinct entity has been challenged and it seems that thyroid antibodies or thyroid status play no role in its pathogenesis. ${ }^{8,13}$ Also, it seems to be uncertain whether persons with thyroid autoimmunity are predisposed to EAT, since the prevalence of autoimmune thyroiditis among school-aged children is $1.2 \%,{ }^{14}$ while Hashimoto encephalopathy is a rare disease. In any event, although the relationship between thyroid autoimmunity and encephalopathy remains unclear at present, it has been noted that the association between high serum antithyroid antibody concentrations and encephalopathy is unlikely to be due to chance. ${ }^{13}$

Another limitation of our theory about Socrates' possible Graves' disease is the fact that the philosopher was executed at the age of seventy and apparently still in good health and, needless to say, without having had any specific therapy for hyperthyroidism during his life. This may be explained by the fact that in some patients, Graves' disease not treated with antithyroid drugs can have a very long course with brief spells of active hyperthyroidism interspersed by long-lasting remissions, ${ }^{15,16}$ while in some instances it may attain a permanent spontaneous remission. Concerning the autoimmune thyroiditis which Socrates possibly had during his childhood, it has been shown that juvenile chronic lymphocytic thyroiditis is often a self-limiting disorder from which complete recovery occurs spontaneously. ${ }^{14}$

\section{REFERENCES}

1. Muramoto O, Englert WG, 2006 Socrates and Temporal Lobe Epilepsy: A Pathographic Diagnosis 2,400 Years Later. Epilepsia 47: 652-654.

2. Plato 1914 Volume I (Euthyphro, Apology, Crito, 
Phaedo, Phaedrus). Translated by H.N. Fowler. Loeb Classical Library, Harvard University Press, Cambridge Mass.

3. Guthrie WKC 1971 Socrates. Cambridge University Press; pp, 66.

4. Nails Debra 2014 "Socrates". The Stanford Encyclopedia of Philosophy (Spring 2014 Edition), Edward N. Zalta (ed).

5. Alper MG, Wartofsky L 2001 Endocrine ophthalmopathy. In Principles and Practice Endocrinology and Metabolism. K. L. Becker (ed) Lippincott Williams \& Wilkins publishers, Philadelphia, PA; pp, 428.

6. Aristoxenus' life of Socrates 2012. In Aristoxenus of Tarentum Discussion. Rutgers University Studies in Classical Humanities, Volume XVII, Carl A. Hoffman (ed) New Brunswick, N.J. Transaction Publishers

7. Ugarte G, Peresa T, 1978 Influence of hyperthyroidism on the rate of ethanol metabolism in man. Nutr Metab 22: 113-118.

8. Armanghue T, Petit-Pedrol M, Dalmau J, 2012 Autoimmune encephalitis in children. J Clild Neurol 27: 1460-1469.

9. Vasconcellos E, Pina-Garza JE, Fakhoury T, Fenichel GM, 1999 Pediatric manifestations of Hashimoto's encephalopathy. Pediatr Neurol 20: 394-398.

10. Mahmud FH, Lteif AN, Renaud DL, Reed AM, Brands
CK, 2003 Steroid-responsive encephalopathy associated with Hashimoto's thyroiditis in an adolescent with chronic hallucinations and depression: case report and review. Pediatrics 112: 686-690.

11. Devinsky O, Schein A, Najjar S, 2013 Epilepsy associated with systemic autoimmune disorders. Epilepsy Currents 13: 62-68.

12. Tsai MH, Lee LH, Chen SD, Lu CH, Chen MT, Chuang YC, 2007 Complex partial status epilepticus as a manifestation of Hashimoto's encephalopathy. Seizure 16: 713-716.

13. Chong JY, Rowland LP, Utiger RD, 2003 Hashimoto encephalopathy. Syndrome or myth? Arch Neurol 60: 164-171.

14. Rallison ML, Dobyns BM, Keating FR, Rall JE, Tyler FH, 1975 Occurrence and natural history of chronic lymphocytic thyroiditis in childhood. J Pediatr 86: 675-682.

15. McLarty DG, Beownlie BEW, Alexander WD, Papapetrou PD, Horton P, 1973 Remission of Thyrotoxicosis during Treatment with Propranolol. BMJ 2: 332-334.

16. Codaccioni JL, Orgiazzi J, Blanc P, Pugeat M, Roulier $\mathrm{R}$, Carayon $\mathrm{P}, 1988$ Lasting remissions in patients treated for Graves' hyperthyroidism with propranolol alone: a pattern of spontaneous evolution of the disease. J Clin Endocrinol Metab 67: 656-662. 